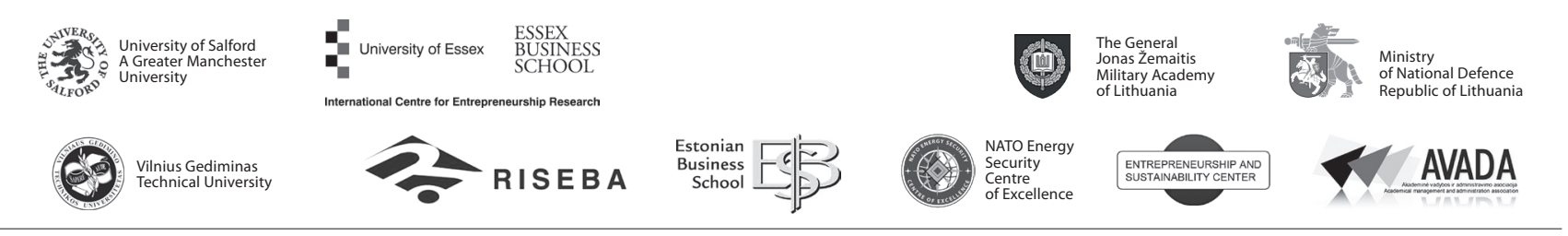

\author{
JOURNAL OF SECURITY AND SUSTAINABILITY ISSUES \\ ISSN 2029-7017 print/ISSN 2029-7025 online \\ 2017 December Volume 7 Number 2 \\ https://doi.org/10.9770/jssi.2017.7.2(9)
}

\title{
SOCIAL COMPONENT IN SUSTAINABLE MANAGEMENT OF LAND RESOURCES
}

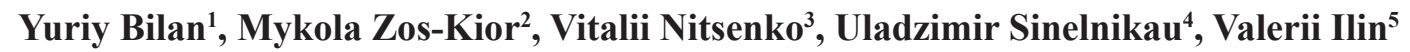 \\ ${ }^{1}$ Centre of Applied Economic Research, Faculty of Management and Economics \\ Tomas Bata University in Zlin, Czech Republic \\ ${ }^{2}$ Department of Management and Logistics \\ Educational and Research Institute of Finance, Economy and Management \\ Poltava National Technical Yuri Kondratyuk University, Poltava, Ukraine \\ ${ }^{3}$ Department of Accounting, Analysis and Audit, \\ Odessa I.I.Mechnikov National University, Odessa, Ukraine \\ ${ }^{4}$ Faculty of Business and Management \\ Belarusian State Agrarian Technical University, Minsk, Belarus \\ ${ }^{5}$ Department of Accounting, Control and Taxation of Agribusiness \\ Kyiv National Economic University named after Vadym Hetman, Kyiv, Ukraine \\ E-mails: '1yuriy_bilan@yahoo.co.uk; 2zoskior@gmail.com; ${ }^{3}$ vitaliinitsenko@gmail.com; \\ vsinelnikov@yahoo.com; 5 villin2015@gmail.com
}

Received 14 March 2017; accepted 26 October 2017

\begin{abstract}
The paper presents a calculation technique and projections on the indices of social efficiency of sustainable land management. The relevance of this study is determined by the authors' technique measuring social, economic and environmental efficiency parity, and its implementation prospects in the context of more sustainable land management in Ukraine as a country that has tremendous potential for its use with a potential worldwide impact on food markets. The paper is aimed at presenting the technique of projecting social efficiency of land management in the context of sustainable development. Projections about the integral efficiency of land management are made according to the developed criteria (productivity, motivation, consistency) using the map of projected effects using conventional and relative, as well as absolute input parameters. This enables improved information support during the formation of national sustainable development strategy of land relations development. The authors substantiate the methodological approaches to planning parameters of land use in dynamics, which are based on determining the impact, including social one, and evaluation of social efficiency of sustainable land management, which allow diagnostics at meso- and macroeconomic scale and can also become tools for scenario modeling.
\end{abstract}

Keywords: management, social efficiency, land resources, sustainable development

Reference to this paper should be made as follows: Bilan, Y.; Zos-Kior, M.; Nitsenko, V.; Sinelnikau, U.; Ilin, V. 2017. The impact of value-added tax on the fiscal sustainability, Journal of Security and Sustainability Issues 7(2): 287-300.

https://doi.org/10.9770/jssi.2017.7.2(9)

JEL: O13, Q15 


\section{Introduction}

Prospects of managing lands of Ukraine's agricultural sector under current conditions have short projection horizons. This phenomenon can be explained by the increasing impact of globalization on all spheres of life in modern society, including land relations issues. Therefore, given the current general trends in the global economy, its agricultural sector and land use in particular, scenario modeling is more likely in making projections of social, economic and environmental efficiency of sustainable management for agricultural lands. For a better picture let us first analyze Ukraine's place in the global and European agriculture (Table 1). To demonstrate the authors' research technique we have chosen Ukraine as a state that has tremendous potential for the land use with a potentially worldwide impact on food markets, having currently low social standards at the same time.

Table 1. Ukraine's place in the global and European agriculture in 2014

\begin{tabular}{|c|c|c|c|c|c|c|c|}
\hline \multirow{2}{*}{ Index } & \multirow{2}{*}{ Ukraine } & \multirow{2}{*}{ World } & \multirow{2}{*}{ Europe } & \multirow{2}{*}{ EU-28 } & \multicolumn{3}{|c|}{$\%$ to (place) } \\
\hline & & & & & world & Europe & EU-28 \\
\hline The land area, million ha & 60,4 & 14900 & 1015,6 & 437,4 & $0,4(44)$ & $5,9(2)$ & $13,9(1)$ \\
\hline The reserves of black soil $\mathrm{mln}$ ha & 28 & 240 & 84 & 18 & 11,7 & 33,3 & $155,6(1)$ \\
\hline The farmland area, million ha & 42,7 & 4810 & 474,8 & 177,7 & 0,9 & 9,2 & $24,0(1)$ \\
\hline The arable land area, million ha & 32,5 & 1340 & 277,8 & 115,7 & 2,4 & 11,7 & $28,1(1)$ \\
\hline The farmland area certified as organic, million ha & 0,28 & 40 & 11,6 & 5,3 & 0,7 & 2,4 & $5,3(11)$ \\
\hline The irrigated land area, million ha & 0,45 & 300 & 20,8 & 11,1 & 0,15 & 2,1 & $4,1(3)$ \\
\hline The investment price, th. USD / ha & 1 & 2 & 4 & 5,5 & 50 & 25 & $18,2(29)$ \\
\hline Exports of grains, $\mathrm{mln} t$ & 34,8 & 312,4 & 130,0 & 38,5 & $11,1(3)$ & $28,1(1)$ & $90,4(1)$ \\
\hline The farmland ha per capita & 0,73 & 0,28 & 0,64 & 0,35 & $260,7(8)$ & $114,1(4)$ & $208,6(2)$ \\
\hline
\end{tabular}

*Summarized by the authors on the material (Pankiv, 2008; Kanash, 2009; Pushover, 2010; Resources FAOSTAT, 2014; Vlasenko \& Namjasenko, 2015; Shubravska, 2015; Khodakivska, 2015).

It should be emphasized that Ukraine today accounts for $90.4 \%$ of grain exports of the European Union, having $28.1 \%$ of the arable lands as compared to the European Union. These are the most important preconditions for its export model with predominantly raw-materials orientation (Kirilenko and Demyanchuk, 2015). However, this model does not provide sustainable development, especially when it comes to social security, fair distribution of economic benefits from exports and environmental efficiency of intensified land use.

Obviously, Ukraine occupies nearly leading positions in Europe in terms of resource availability but at the same time - secondary ones in terms of investment in these resources, including land (irrigation, organic farming). So there is a great niche for investment, for foreign investors in particular, who might implement their joint projects into logistics infrastructure and other facilities as long as all risks related to national security are controlled and also, as long as these foreign investors are ready to confirm their projects would indeed contribute to national sustainable development, and not only in short, but also in a longer term. The main objectives of the study are synthesis of theoretical principles of social efficiency of sustainable land management, presentation of techniques for assessing the level of social efficiency of land management, demonstration of the sequence of formation of projected influences maps and the authors' techniques for analyzing the elements of the matrix of projected efficiency values.

In the study we applied the following methods and techniques: abstraction, analysis and synthesis, economic and statistical one for combining the qualitative and quantitative aspects; special ones (expert evaluation, neural networks, sample observation) for processing and synthesizing statistics and their representation in the most informative manner; program and target-oriented method to determine the tools of efficient management of land resources; determinate and repeated sampling to form the data representativity; benchmarking assessment, grouping through the use of the common software (MS EXCEL) and special software (Deductor Studio); systemic approach for predicting the efficiency of management. 
The logic of the study is defined as follows. Firstly, we take for granted the position of parity of social, economic and environmental efficiency of land management in evaluating the integral value. Secondly, based on the previous long-lasting studies (Zos-Kior et al., 2014; Zos-Kior, 2015) we take as a starting point the criterion approach to structuring the social efficiency of land resources management using expert estimates of weight of each indicator and criterion. Thirdly, an assumption was substantiated regarding the interplay of certain types of efficiency and accordingly strengthening / weakening their impact on the integrated efficiency of land management. Fourthly, the authors took as a starting point the division of representatives of land interests into mini-, microagents, state, common, regional and global agents; directly for the present study the authors sorted out the indices, which the state as the key agent of land interests focuses on in order to reach national sustainable development. Fifthly, the score technique of calculating the impact of individual indices on the changes of integrated efficiency was taken as a starting point, and due to that an assumption was made and substantiated about the possibility of relevant changes and projections about the indices accordingly through the scores in relative and absolute terms, allowing their practical application.

\section{Literature review.}

In agriculture decision-making relating to technologies, apart from economic and environmental ones, is affected by at least two categories of social factors:

- Macrosocial - belonging to structural ones that are beyond the business manager control (Reiff et al., 2016, Czyżewski and Smędzik-Ambroży, 2015; Dedina and Sánová, 2013);

- Microsocial - the ones directly relating to the actions of economic agents (Chakir, Gallo, 2013; Stukach, 2013; Delattre, Chanel, Livenais \& Napoléone, 2015; Homolac and Karel, 2016).

Macrosocial factors include demographics; poverty (farmers will use the land, getting much profit in a short period of time, and taking care of their own survival, not the preservation of natural resources); public policy (Stukach, 2013; Chakir, Gallo, 2013; Delattre, Chanel, Livenais, \& Napoléone, 2015).

Microsocial factors (strongly influencing decision-making on the use of technologies) comprise a measure of awareness of the problem and ongoing operations; access to information; economic efficiency of the subject of the system as a whole and its individual elements; the degree of knowledge acquisition and skills development, such as about the technologies that directly affect the behavior of a business man on land (Stukach, 2013; Chakir and Gallo, 2013; Delattre, Chanel, Livenais \& Napoléone, 2015).

At the enterprise level social efficiency can be formulated as the degree of meeting the needs of the enterprise employees, and its owners for the means and conditions in terms of life support. At the state and regional level social efficiency is characterized by the level of employment and reduction of unemployment, increasing pensions, etc. (Andreychuk, 2006; Cockfield, and Botterill, 2016). The basis for the formation of social efficiency is economic efficiency. It is only the economic effect created in the economic activity which can be a source of satisfaction of the whole spectrum of social needs of the population. So objectively there is a relationship: the higher the economic efficiency, under the other equal conditions, the higher will be the social efficiency, and vice versa. Between these kinds of efficiency there exists an opposite relationship, an increase in social efficiency results in higher productivity of employees and hence the economic efficiency of production increases, i.e. in this case we have a multiplicative lever (Andreychuk, 2006). This regularity should be used in assessing the efficiency of land management.

Therefore, according to Diyesperov, the correlation between land and labor resources is especially important both in the economic and social context. It is easily expressed through the index of land content of workplace, i.e. an area of land per average employee per annum, including employees directly in crop and livestock production. Rising productivity leads to an increase in land content and intensification of production structures makes an impact in the opposite direction (Diesperov, 2014; Velychko, 2015). Currently, reduction in the share of the gross production of high-intensity types does not make it possible to raise wages of agricultural workers while increasing profits of the asset holders. 
We agree with the scientists' opinion that the criterion of social efficiency is sustainable development of the community through the optimal combination of income and leisure time, the largest rural employment (Budzak, 2009; Kvasha, 2009; Knoke, Paul, Härtl, Castro, Calvas, \& Hildebrandt, 2009; Ward, Yin, Dargusch, Fulton \& Ammar, 2017; Yerznkyan et al., 2017; Simanaviciene et al., 2017, Urbaniec, 2015 ). Thus, according to Andriychuk, the main measure of the efficiency of this type is proportion of the profit aimed at social events to the total mass of net profit per average employee (Andreychuk, 2006). Based on the logic, the enterprise, which increased salaries renovated the country club and repaired the road (i.e. it was socially active), but for a year it worked with a loss, is less socially efficient than the enterprise which obtained profits, but confined itself to the payment of wages. To some extent this index reflects the level of social efficiency of land management at an agricultural enterprise, and for the entire agricultural sector it can be provisionally calculated through the calculation-constructive techniques.

Among other things, it is necessary to make efficient use of all kinds of resources to enhance the social efficiency of Ukraine's agricultural sector. They should be used efficiently, and their allocation among various entities needs to be explored (Diesperov, 2014; Ward et al., 2017). For example, 70\% of agricultural land in the UK is owned by $1 \%$ of the population (feudal monopoly character of the land use) (Shubravska, et al., 2014; Delattre et al., 2015), which not only leads to higher prices for land management facilities, but also to the inflated food prices. Hence, the need to analyze the corresponding index in the present study.

Numerous findings of Ukrainian scientists suggest that latifundia dominance can lead to social collapse of rural areas and deprive the state of the sources of intellectual, ethnic and demographic potential renovation (Golyan, 2012). At the same time agricultural holding companies provide the highest wages and rents in rural areas, have the highest capital-labour ratio and hence the highest productivity. According to the authors, this necessitates the use of the index "value growth rate of labor productivity to the growth rate of the land content of work place."

In addition, there is a big scientific and practical problem comncerning identification of the factors that most influence the content of decisions and specific actions of economic agents about the systems of crop and livestock farming, which once again confirms the importance of identifying the dependence of solutions on the economic interests (Stukach, 2013). In other words, in the process of decision-making and their implementation, the motivation stage should be given considerable attention. This is possible through the harmonization of the interests of the owners, employees and rural communities (Pogrishuk. and Pogrishuk, 2015; Sutton, Anderson, Costanza \& Kubiszewski, 2016).

Let us consider the issue taking as an example current average indices of a rural community in Ukraine. Suppose that the actual development of the Ukrainian village will be determined primarily by small businesses. This vision is due to the recent trends in the example of the villages of Zhmerynka and Vinnytsa districts of Vinnytsia oblast in 2007-2014, which clearly showed the absence of any significant effect of agricultural holding companies or state programs on the state of rural communities. Trend analysis of the situation over the past decades has shown that the prospects for the development of rural communities is primarily due to the degree of intensification of widely diversified small business and capitalizing on the basis of cash flows generated in the local economies. The use of this fact in the process of adjustment of the regulatory policy is a key one (Moroz, Karachina, Semtsov, \& Mandziuk, 2015).

It should be noted that the village currently has unfavorable legal and socio-economic conditions sustainable for small businesses, although the average family in rural areas, such as Central Ukraine, with several land parcels, has similar or even superior land supply figures regarding the area of an average farm in Western Europe (20 hectares). The peasantry is not a group of agricultural agents that are subject to exploitation, and their behavior type is mutually coordinated with the type of behavior of all agent groups. Formalizing opportunistic relationships provides for a particular type of contractual relationships. The transition from the opportunistic model to an ideal (or more constructive) model of economic relations will be preceded by a change of public contracts (changing attitudes to rural businesses) between major groups of agents (Moroz, Karachina, Semtsov, Mandziuk, 2015; Delattre, Chanel, Livenais, and Napoléone, 2015), with the main indices of social efficiency, 
as identified by the authors, being peasants desocialization (which manifests itself, for example, by them moving to the city); the problem of peasants' access to money; the proportion of people self-employed on their own land, that determine the prospects of land management in the agricultural sector of Ukraine.

Given the variety of approaches to the indices and determining the level of social efficiency of land management, we offer our own technique which is supposed to contribute to sustainable development of land use and land management in Ukraine.

\section{Evaluating the level of social efficiency of land management}

From the total array of the indices of social efficiency of land management it is advisable to distinguish those that are important analytical materials at the national level. Among all the studied parameters of social efficiency of land management (total 40) the state, an agent of land interests, responds to 33 indices.

Considering the above and taking notice of the authors' opinions and expert judgement, we introduce a system of evaluation criteria of social efficiency of managing land resources in the agricultural sector of the economy (Fig. 1).

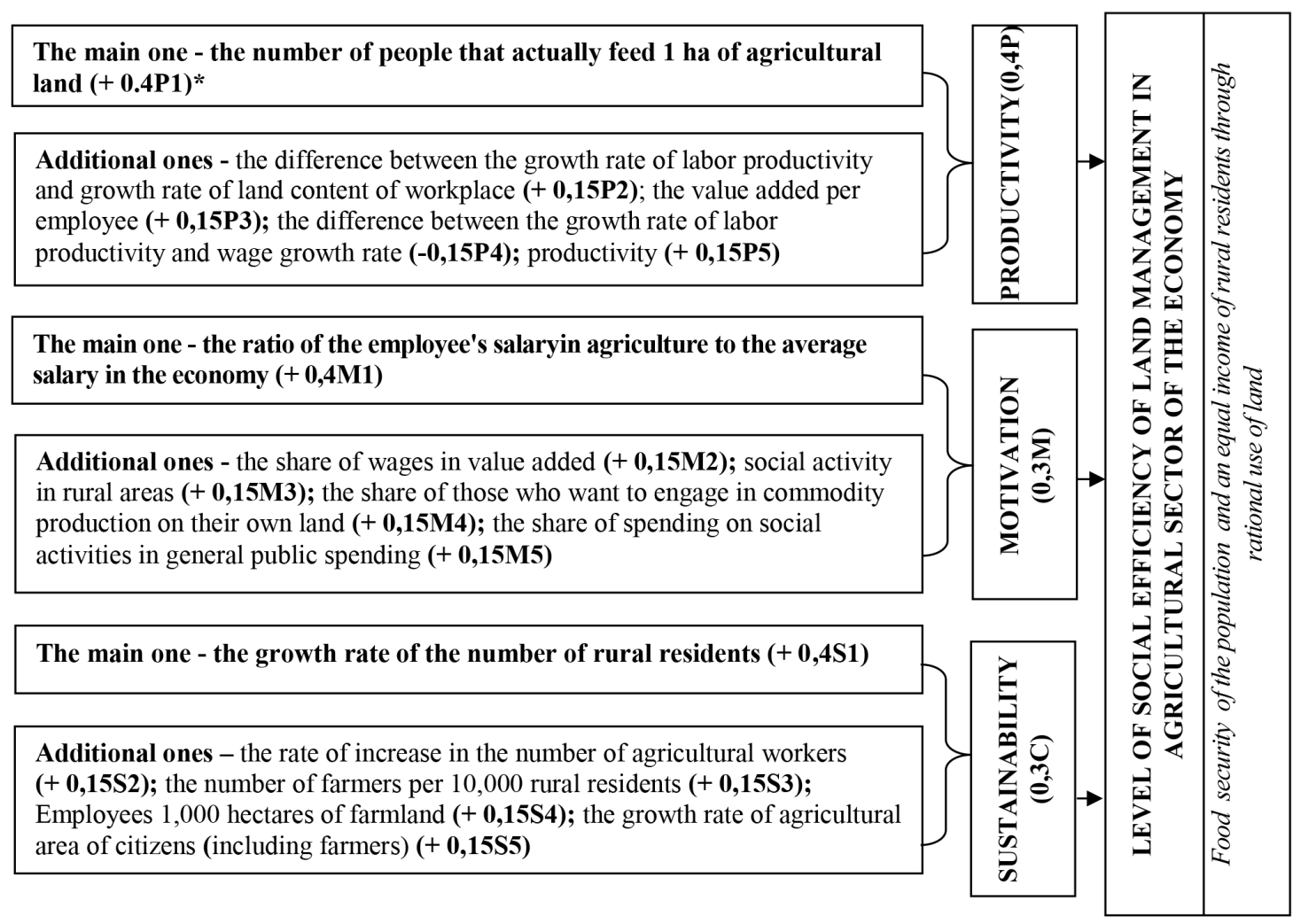

Figure 1. The system of criteria and indices for measuring social efficiency of land management in the agricultural sector of the economy (developed by the authors using the results of an expert estimate)

* +0.40 means that the index has weight of 0.40 and is a stimulus (from "-" - a deterrent).

The index of "social activity in rural areas" requires some additional explanations. It shows the frequency and regularity of all social activities in rural areas (the average number of service cooperatives per 100,000 rural residents (based on the following data - household income 80 USD per month, a household - an average of 2.6 persons, the average turnover of one cooperative under the best conditions 40,000 USD monthly, at least 77 cooperatives per 100,000 people), as well as putting the housing into operation in rural areas, $\mathrm{M}^{2}$ per 100 villagers $\left(1 \mathrm{M}^{2}\right.$ per inhabitant per year, i.e. $30 \mathrm{~m}^{2}$ per inhabitant per 30 years by the index method). 
Scrutiny of the methodological principles of social efficiency of land management has made it possible to offer the calculation of the level of social efficiency of land management (according to the criteria of productivity, motivation, sustainability). The identified criteria and indices are dynamic, as they are guided by reference to a different base of indices that depend on the level of intensification and activity of land interest agents. And the level of social efficiency of land management was considered as the food security of the population and an equal income of rural residents through rational use of land.

\section{Formation of the maps of projected impacts}

In view of the above, the authors made an estimation of the projected impacts of the economic efficiency indices of land management based on the data of 2014 in Ukraine according to the model of determining projected values, the essence of which is set out below. Let $\lambda$ is an arbitrary figure. It defines two functions on the set of all indices. Function $f_{\lambda}\left(a_{i j k}\right)$ equals 1 if the change of parameter $\lambda$ causes a change of the index $\mathrm{a}_{\mathrm{ijk}}$, and it equals 0 if the relationship between $\lambda$ and $\mathrm{a}_{\mathrm{ijk}}$ is missing. Function $\mathrm{g}_{\lambda}\left(\mathrm{a}_{\mathrm{ijk}}\right)$ defines the regression coefficient of index $\mathrm{a}_{\mathrm{ijk}}$ on index $\lambda$. Then, with the $\lambda$ index change by the value of $\Delta_{\lambda}$, the change of the integrated efficiency of land management is defined by the equation (1):

$$
\Delta=\sum_{i=1}^{3} \sum_{j=1}^{3} \beta_{i j} \sum_{k=1}^{5} \alpha_{i j k} f_{\lambda}\left(a_{i j k}\right) g_{\lambda}\left(a_{i j k}\right) \Delta_{\lambda} .
$$

The following symbols are proposed for successful graphic and formalized representation of the model elements:

\section{Economic efficiency:}

1.1. Land output (L), value added per 1 ha of agricultural land (L1); profits per 1 ha of farmland (L2); the difference between the rate of increase in land value and growth rate of prices for other nonresidential real estate (L3); the difference between the growth rate of gross output and acreage growth rate (L4); rent rate (L5).

1.2. Productive motivation (PM): the difference between the level of profitability of agricultural activities and the average rate on deposits (PM1); the profitability level of agricultural activities (PM2); the growth rate of profit from the sale of agricultural products and services (PM3); the share of exports in total net output of the agricultural sector (PM4); the net profit attributable to a founder of the enterprise per year (PM5).

1.3. Diversification (D): the share of animal products in relation to gross production (D1); the share of perennial plants in the structure of farmland (D2); the share of household arable land that was not under crop (D3); power supply capacity of agricultural enterprises (D4); economic activity in rural areas (D5).

II. Social efficiency (presented in Figure 1):

III. Environmental efficiency:

3.1. Anthropogenic pressures (AP): using fertilizers on 1 hectare of cultivated area (AP1); using plant protection products on 1 hectare of cultivated area (AP2); land use per unit of gross output (AP3); the share of sunflower and oilseed rape in the structure of sown areas (AP4); livestock density (AP5).

3.2. Reproduction (R), environmental and agrochemical soil assessment (R1); balance of humus (R); the share of cultivated area enriched with organic fertilizers (R3); the share of cultivated area enriched with mineral fertilizers (R4); human load factor (R5).

3.3. Harmonization $(\mathrm{H})$ : the share of the eroded land area in the structure of agricultural land $(\mathrm{H} 1)$; the share of organic farms per 10,000 agricultural enterprises (including farmers) (H2); the share of meadows and pastures in the total area of farmland (H3); the proportion of perennial grasses in the structure of sown areas (H4); environmental activities in rural areas (H5).

The results of the calculations show that, in addition to direct effects of some indices on the aggregated value of the economic and environmental efficiency of land management, the aggregate value of social efficiency of land management suffered indirect effects (Table 2). 
Table 2. The map of projected impacts of the indices of economic and environmental efficiency of Ukraine's land management, based on data of 2014 *

\begin{tabular}{|c|c|c|c|c|c|c|c|c|c|}
\hline \multicolumn{9}{|c|}{ Impact on the efficiency } \\
\hline \multicolumn{9}{|c|}{ of the economic efficiency indices } & \multicolumn{4}{c|}{ of the environmental efficiency indices } \\
\hline index & economic & social & environmental & integral & index & economic & social & enviromental & integral \\
\hline L 1 & 0,194 & 0,223 & 0 & 0,417 & AP 1 & 0 & 0,144 & 0,223 & 0,366 \\
\hline L 2 & 0,334 & $-0,004$ & 0 & 0,330 & AP 2 & 0 & 0 & 0,060 & 0,060 \\
\hline L 3 & 0,060 & 0 & 0 & 0,060 & AP 3 & 0,137 & 0,156 & 0,085 & 0,378 \\
\hline L 4 & 0,060 & 0 & 0 & 0,060 & AP 4 & 0,029 & 0,011 & 0,191 & 0,231 \\
\hline L 5 & 0,060 & 0 & 0 & 0,060 & AP 5 & 0,173 & $-0,167$ & 0,683 & 0,688 \\
\hline PM 1 & 0,120 & 0 & 0 & 0,120 & R 1 & 0 & 0 & 0,120 & 0,120 \\
\hline PM 2 & 0,045 & 0 & 0 & 0,045 & R 2 & 0,009 & 0,055 & 0,102 & 0,167 \\
\hline PM 3 & 0,045 & 0 & 0 & 0,045 & R 3 & $-0,084$ & 0 & 0,700 & 0,616 \\
\hline PM 4 & 0,193 & 0,202 & 0,008 & 0,403 & R 4 & 0 & 0,000 & 0,080 & 0,080 \\
\hline PM 5 & 0,045 & 0 & 0 & 0,045 & R 5 & 0 & 0 & 0,045 & 0,045 \\
\hline D 1 & 0,119 & 0,160 & $-0,023$ & 0,256 & H 1 & $-0,027$ & 0,091 & 0,096 & 0,160 \\
\hline D 2 & 0,045 & 0 & 0 & 0,045 & H 2 & 0 & 0 & 0,045 & 0,045 \\
\hline D 3 & 0,045 & 0 & 0 & 0,045 & H 3 & 0 & 0 & 0,045 & 0,045 \\
\hline D 4 & 0,045 & 0 & 0 & 0,045 & H 4 & 0 & 0 & 0,172 & 0,172 \\
\hline D 5 & 0,045 & 0 & 0 & 0,045 & H 5 & 0 & 0 & 0,045 & 0,045 \\
\hline
\end{tabular}

* Developed by the authors

The positive impact of the value added per 1 ha of agricultural land (L1) on social efficiency is due to the increase of its absolute value, and therefore its structural elements, including wages. Noteworthy is the reverse impact of L2 (gains per 1 hectare of farmland) on social efficiency, which is due to the very weak coupling of profits and wages and deductions for social events. In addition, according to the authors' studies L2 directly correlates with the land content of workplace, which means a steady downsizing of the agricultural sector. The share of exports in total net output of the agricultural sector (PM4) has even a more significant social impact than the economic one, which can be explained by the globalization of social influence -/wages in a country with an open economy are gradually approaching the wages in countries that use similar technologies. In addition, the transition from a high yield stage to the stage of sustainable high yield has a clearly positive impact on the environmental component. A similar situation exists with the proportion of animal products in relation to gross production (D1).

The impact suffered by social efficiency can be explained by the fact that raising livestock is more labour intensive and therefore there is a need to involve more staff in the process. It is also necessary to focus on the D1 negative impact on the environmental efficiency, which the authors explain by the significant influence on the environmental efficiency of the land management index per gross output unit. As the growth in livestock at the agricultural enterprises is always directly proportional to the number of livestock in household farms, the value of land use per unit of gross output suffers even a more negative impact.

Only three indirect impacts are caused by the indicators of social efficiency of land management (Table 3 ). Thus, the number of people that actually feed 1 ha of agricultural land (P1), has a positive impact on the economic estimate due to the increased land output. The growth rate of the number of rural residents (S1) positively influences the economic efficiency by increasing the share of gross production of the househould farms. Accordingly, this reason had a positive impact on the environmental efficiency (in agriculture, in addition to technologies, a higher proportion of livestock production in the gross output of household farms is taken into account). 
Table 3.The map of projected impacts of the indices of social efficiency of land management in Ukraine based on data of 2014 *

\begin{tabular}{|c|c|c|c|c|}
\hline \multirow{2}{*}{ Index } & \multicolumn{3}{|c|}{ Impact on the efficiency } \\
\cline { 2 - 5 } & economic & social & 0 & environmental \\
\hline P 1 & 0,009 & 0,164 & 0 & 0,173 \\
\hline P 2 & 0 & 0,060 & 0 & 0,060 \\
\hline P 3 & 0 & 0,060 & 0 & 0,060 \\
\hline P 4 & 0 & 0,060 & 0 & 0,082 \\
\hline P 5 & 0 & 0,082 & 0 & 0,120 \\
\hline M 1 & 0 & 0,120 & 0 & 0,045 \\
\hline M 2 & 0 & 0,045 & 0 & 0,045 \\
\hline M 3 & 0 & 0,045 & 0 & 0,045 \\
\hline M 4 & 0 & 0,045 & 0 & 0,045 \\
\hline M 5 & 0 & 0,045 & 0,022 & 0,157 \\
\hline S 1 & 0,099 & 0,036 & 0 & 0,045 \\
\hline S 2 & 0 & 0,045 & 0 & 0,045 \\
\hline S 3 & 0 & 0,045 & 0 & 0,045 \\
\hline S 4 & 0 & 0,045 & 0 & 0,045 \\
\hline S 5 & 0 & 0,045 & & \\
\hline
\end{tabular}

* Developed by the authors.

Most indirect impacts are caused by the environmental efficiency indices of land management. Thus, an increase in use of chemical fertilizers per 1 ha of cultivated area (AP1) has a positive effect on the economic efficiency of land management through increased gross yield, and hence the total household resources (in this case -wages and payment of rent). Land use per unit of gross output (AP3) has a positive effect on the economic efficiency of land management through increased land output and on the social efficiency of land management - through increased labour productivity, all other factors being equal. Regarding the share of sunflower and oilseed rape in the structure of sown areas (AP4), the authors' research findings show that more diversified farms are more profitable, moreover, the production process can involve more personnel which can be observed on the impacts map.

The negative impact of livestock density (AP5) on the social efficiency of land management can be explained by the decline of livestock industry, and hence a much lower level of value added per one employee. The positive impact of the same index on the economic efficiency of land management is caused by the multiplicative effect of the production diversification. As for the positive impact of the balance of humus (R2) on the economic and social efficiency, any increase of this index means improvement of the quality of land resources $\rightarrow$ productivity + product quality $\rightarrow$ gross yield + actual price $\rightarrow$ revenue of all land interest agents. The share of cultivated area enriched with organic fertilizers (R3) has a negative impact on the economic efficiency of land management due to the high cost of manure and work on its use, as well as impossibility of an objective calculation of economic benefits due to its long-term nature.

Reduction in the proportion of the eroded land areas in the structure of agricultural land (H1) is due to the additional costs which causes decline in the economic efficiency of land management and, on the contrary, it increases the social efficiency of land management due to the possibility to get additional resources by the households. To predict the change in the value of integrated efficiency of land management adopting the proposed methodological approach we used the software which, inclusive of the interplay (see Table 2-3), makes it possible to calculate the projected rating of the index impact on the estimate of integrated efficiency of land management. One of the variants of the projection is presented in Table 4. The 15 most influential parameters include 9 environmental, 4 economic, and 2 social ones. 
Table 4. Projected rating of the index impacts on the estimate of the integrated efficiency of land management based on the data of 2014 *

\begin{tabular}{|c|c|c|c|c|c|}
\hline Index & Impact & Index & Impact & Index & Impact \\
\hline AP 5 & 0,688 & R 1 & 0,120 & D 2 & 0,045 \\
\hline R 3 & 0,616 & M 1 & 0,120 & D 3 & 0,045 \\
\hline L 1 & 0,417 & R 4 & 0,080 & D 4 & 0,045 \\
\hline PM 4 & 0,403 & P 5 & 0,080 & D 5 & 0,045 \\
\hline AP 3 & 0,378 & L 3 & 0,060 & R 5 & 0,045 \\
\hline AP 1 & 0,366 & L 4 & 0,060 & $\mathrm{H} 2$ & 0,045 \\
\hline L 2 & 0,330 & L 5 & 0,060 & H 3 & 0,045 \\
\hline D 1 & 0,256 & AP 2 & 0,060 & M 2 & 0,045 \\
\hline AP 4 & 0,231 & P 2 & 0,060 & M 3 & 0,045 \\
\hline $\mathrm{H} 4$ & 0,172 & P 3 & 0,060 & M 4 & 0,045 \\
\hline R 2 & 0,167 & P 4 & 0,060 & M 5 & 0,045 \\
\hline P 1 & 0,167 & PM 2 & 0,045 & S 2 & 0,045 \\
\hline H 1 & 0,160 & PM 3 & 0,045 & S 3 & 0,045 \\
\hline S 1 & 0,160 & PM 5 & 0,045 & S 4 & 0,045 \\
\hline PM 1 & 0,120 & H 5 & 0,045 & S 5 & 0,045 \\
\hline
\end{tabular}

* Developed by the authors

The forecast argues that a change in one of the indicators (e.g. by 1) by a certain value (in conventional assessment points) lead to a change in the value of the integrated efficiency of land management. For example, an increase by 1 point in value of AP1 (livestock density) leads to an increase by 0.69 points in the value of integrated efficiency of land management. In other words, an increase in the livestock density by $59 \%$ ( 1 point of the value of this index equals 59\%) increases the value of integrated efficiency of land management by $2.89 \%$ ( 1 point of the value of integrated efficiency of land management equals $4.18 \%$, respectively 0.69 points $2.89 \%$ ). If in 2014 the livestock density was 31.5 conventional heads per 100 hectares of farmland, the absolute growth by $59 \%$ will be 18.6 conventional heads per 100 hectares of farmland. In terms of cows ( 1 conventional head $=1 \mathrm{cow}$ ) and the entire area of agricultural land in Ukraine that means the need to increase the livestock by 6,501 conventional heads. The second most important (by the ability to change the value of integrated efficiency of land management) index is R3 (the proportion of cultivated area enriched with organic fertilizers), again linked with the development of animal husbandry. This indicates that it is impossible to increase the efficiency of land management without diversifying production.

\section{Demonstration of the elements in the matrix of projected efficiency values to achieve sustainability}

Based on the previous studies, we have formed a matrix of projected values of the integrated efficiency (IE) of land management in the agricultural sector for all analyzed criteria to achieve sustainability. Let us consider the social criteria. According to Table 5, a change by 1 point (a transition from estimate 4 points to 5 points) of the number of people that actually feed 1 ha of agricultural land (P1), increases the integrated efficiency of land management by 0.173 points (or $0.71 \%$ ), which is equivalent to P1 increased by $2.9 \%$. In absolute terms, this means an increase of $\mathrm{P} 1$ from 1.37 to 1.41 people per 1 ha of agricultural land, which is equal to additional 906.9 million USD of the gross output at actual prices of 2014. Under these conditions, Ukraine will feed 65.4 million people instead of 63.6 million people. 
Table 5. Projected values of integrated efficiency (IE) of land management in the agricultural sector under the influence of changes by 1 point in the "productivity" criterion *

\begin{tabular}{|l|c|c|c|c|l|}
\hline \multirow{2}{*}{ Index } & \multicolumn{2}{|c|}{ IE change } & \multicolumn{3}{|c|}{ Change and projection about indicators } \\
\cline { 2 - 6 } & point & $\%$ & point & $\%$ & \multicolumn{2}{c|}{ In absolute terms } \\
\hline $\begin{array}{l}\text { The number of people that actually feed 1 ha of } \\
\text { agricultural land (P1) }\end{array}$ & 0,173 & 0,71 & $4 \rightarrow 5$ & $+2,9$ & $\begin{array}{l}1,37 \rightarrow 1,41 \text { people per 1 ha of agricultural } \\
\text { land, equal to gross output at current prices of } \\
906.9 \text { million USD additionally }\end{array}$ \\
\hline $\begin{array}{l}\text { The difference between the growth rate of labor } \\
\text { productivity and growth rate of land content of } \\
\text { workplace (P2), } \%\end{array}$ & 0,060 & 0,25 & $0 \rightarrow 1$ & $+6,0$ & $-6 \rightarrow 0 \%$ \\
\hline $\begin{array}{l}\text { The value added per employee (P3), thousand } \\
\text { USD / person }\end{array}$ & 0,060 & 0,25 & $3 \rightarrow 4$ & $+32,5$ & $\begin{array}{l}5,588 \rightarrow 7,404 \text { thousand USD / person, equal } \\
\text { to an additional added value of 952,85 mln } \\
\text { USD }\end{array}$ \\
\hline $\begin{array}{l}\text { The difference between the growth rate of labor } \\
\text { productivity and wage growth rate (P4), \% }\end{array}$ & 0,060 & 0,25 & $-9 \rightarrow-8$ & $+0,1$ & \begin{tabular}{l}
$4,1 \rightarrow 4,0 \%$ \\
\hline Productivity, USD/person (P5)
\end{tabular} \\
\hline
\end{tabular}

* Developed by the authors

A change by 1 point (transition from 0 to 1point) of the difference between the growth rate of the land content of work place and growth rate of labor productivity (P2), increases the integrated efficiency of land management by 0.060 (or $0.25 \%$ ), which is equivalent to an increase of P2 by $6.0 \%$. In absolute terms, this means an increase of $\mathrm{P} 2$ from -6 to $0 \%$, which means aligning of their growth.

A change by 1 point of the added value per employee (P3) - transition of the estimate from 3 to 4 points - leads to increased integrated efficiency of land management by 0.060 (or $0.25 \%$ ), which is equivalent to an increase in P3 by 32.5\%. In absolute terms, this means an increase in P3 from 5.588 to 7.404 thousand USD /person, equal to an additional added value in the amount of $952,85 \mathrm{mln}$ USD.

A change by 1 point in the difference between the growth rate of labor productivity and wage growth rate (P4) transition from the estimate of -8 to -9 points - leads to increased integrated efficiency of land management by 0.060 (or $0.25 \%$ ), which is equivalent to an increase in $\mathrm{P} 4$ by $0.1 \%$, which is a minor change. In absolute terms, this means reducing P4 from 4.1 to $4 \%$. A 1 point change in labor productivity (P5) - transition from the estimate of 8 points to 9 points - leads to increased integrated efficiency of land management by 0.060 (or $0.25 \%$ ), which is equivalent to P5 increase by $5.4 \%$. In absolute terms this means P5 increase from 9.112 to 9.604 thousand USD / person, equal to an additional 492 USD / person.

According to Table 6, a 1 point change (transition of the estimate from 5 points to 6 points) of the ratio of the employee's wages in agriculture to the average wages in the economy (M1), which increases the integrated efficiency of land management by 0.120 points (or $0.50 \%$ ), is equivalent to an increase in M1 by $5.0 \%$. In absolute terms, this means an increase in M1 from 0.71 to 0.76 , equal to wages of 105.8 USD per month, by 6.75 USD more than the current wages in 2014. 
Table 6. Projected values of integrated efficiency (IE) of land management in Ukraine's agricultural sector under the influence of changes by 1 point in the»motivation» criterion *

\begin{tabular}{|c|c|c|c|c|c|}
\hline \multirow{2}{*}{ Index } & \multicolumn{2}{|c|}{ IE change } & \multicolumn{3}{|r|}{ Change and projection about indicators } \\
\hline & point & $\%$ & point & $\%$ & In absolute terms \\
\hline $\begin{array}{l}\text { The ratio of the employee's salary in } \\
\text { agriculture to the average salary in the } \\
\text { economy (M1) }\end{array}$ & 0,120 & 0,50 & $5 \rightarrow 6$ & $+5,0$ & $\begin{array}{l}0,71 \rightarrow 0,76, \text { equal to wages of } 105.8 \text { USD per } \\
\text { month, by } 6.75 \text { USD more than the actual one }\end{array}$ \\
\hline $\begin{array}{l}\text { The share of wages in value added (M2), } \\
\%\end{array}$ & 0,045 & 0,21 & $5 \rightarrow 6$ & $+2,41$ & $15,1 \rightarrow 17,51 \%$ \\
\hline Social activity in rural areas (M3), point & 0,045 & 0,21 & $1 \rightarrow 2$ & $+6,0$ & $\begin{array}{l}5 \rightarrow 11 \text { points, equal to additional construction or } \\
\text { putting the housing into operation in rural areas of } \\
10,160.2 \text { thousand } \mathrm{m}^{2} \text { of the total area, or an increase } \\
\text { in the number of registered agricultural service } \\
\text { cooperatives by } 1,272 \text {, or an intermediate option }\end{array}$ \\
\hline $\begin{array}{l}\text { The share of those who want to engage } \\
\text { in commodity production on their own } \\
\text { land (M4), \% }\end{array}$ & 0,045 & 0,21 & $5 \rightarrow 6$ & $+1,21$ & $\begin{array}{l}16,3 \rightarrow 17,51 \% \text {, equal to an increase by } 2.42 \% \text { in the } \\
\text { proportion of households in rural areas that engage } \\
\text { employees or an increase by } 2.42 \% \text { in the proportion } \\
\text { of households in rural areas with agricultural } \\
\text { machinery, or an intermediate option }\end{array}$ \\
\hline $\begin{array}{l}\text { The share of spending on social } \\
\text { activities in general public spending } \\
\text { (M5), \% }\end{array}$ & 0,045 & 0,21 & $5 \rightarrow 6$ & $+0,31$ & $2,7 \rightarrow 3,01 \%$ \\
\hline
\end{tabular}

* Developed by the authors

Regarding the share of wages in the value added (M2), its change by 1 point (transition from the estimate of 5 points to 6 points) increases integrated eficiency of land management by 0,045 (or $0.21 \%$ ), which is equivalent to an increase of M2 by $2.41 \%$. In absolute terms, this means an increase of M2 from 15.1 to $17.51 \%$, which is a very significant share. A 1 point change of social activity in rural areas (M3) - transition from the estimate of 1 point to 2 points - results in an increase of integrated efficiency of land management by 0,045 (or $0.21 \%$ ), which is equivalent to an increase of M3 by $6.0 \%$. In absolute terms, this means an increase of M3 from 5 to 11 points, equal to additional construction or putting the housing into operation in rural areas of 10,160.2 thousand $\mathrm{m}^{2}$ of the total area, or an increase in the number of registered agricultural service cooperatives by 1,272 , or an intermediate option. A 1 point change in the share of those wishing to engage in commodity production on their own land (M4) - transition from the estimate of 5 points to 6 points - results in an increase of integrated efficiency of land management by 0,045 (or $0.21 \%$ ), which is equivalent to an increase in M4 by $1,21 \%$. In absolute terms, this means an increase of M4 from 16.3 to $17.51 \%$, which is equal to an increase by $2.42 \%$ in the proportion of households in rural areas that engage employees, or an increase by $2.42 \%$ in the proportion of households in rural areas with agricultural machinery, or an intermediate option. A 1 point change in the share of spending on social programs in total expenditures (M5) - the transition from the estimate of 5points to 6 points - results in an increase of integrated efficiency of land management by 0,045 (or $0.21 \%$ ), which is equivalent to an increase in M5 by $0,31 \%$. In absolute terms, this means an increase in M5 from 2.7 to 3.01\%, which is quite significant for this index.

According to Table 7, a 1 point change (transition from the estimate of 1 point to 2 points) in the growth rate of the number of rural residents (S1), which increases the integrated efficiency of land management by 0.157 points (or $0.67 \%$ ), is equivalent to an increase in S1 by $0,07 \%$. In absolute terms, this means an increase in S1 from -0.57 to -0.50 , which is equivalent to a decrease in the number of rural residents by 9.33 thousand people per annum. 
Table 7. Projected values of integrated efficiency (IE) of land management in the agricultural sector of Ukraine under the influence of changes of "sustainability" criterion by 1 point *

\begin{tabular}{|l|c|c|c|c|l|}
\hline \multirow{2}{*}{ Index } & \multicolumn{2}{|c|}{ IE change } & \multicolumn{3}{|c|}{ Change and projection about indicators } \\
\cline { 2 - 7 } & point & $\%$ & point & $\%$ & \multicolumn{1}{c|}{ In absolute terms } \\
\hline $\begin{array}{l}\text { The growth rate of the number of rural } \\
\text { residents (S1), } \%\end{array}$ & 0,157 & 0,67 & $-2 \rightarrow-1$ & $+0,07$ & $\begin{array}{l}-0,57 \rightarrow-0,50 \% \text {, equivalent to a decrease in the number of } \\
\text { rural residents by 9.33 thousand people per annum }\end{array}$ \\
\hline $\begin{array}{l}\text { The rate of increase in the number of } \\
\text { agricultural workers (S2), } \%\end{array}$ & 0,045 & 0,21 & $-10 \rightarrow-9$ & $+1,7$ & $\begin{array}{l}-6,2 \rightarrow-4,5 \% \text {, equivalent to a decrease in the number of } \\
\text { employees in agriculture by 9,51 thousand people per an- } \\
\text { num }\end{array}$ \\
\hline $\begin{array}{l}\text { The number of farmers per 10,000 rural } \\
\text { residents (S3) }\end{array}$ & 0,045 & 0,21 & $10 \rightarrow 10$ & $+\mathrm{n}$ & $30 \rightarrow 30+\mathrm{n}$ units equal to n additional units of farmers \\
\hline $\begin{array}{l}\text { Employees 1,000 hectares of farmland } \\
\text { (S4) }\end{array}$ & 0,045 & 0,21 & $3 \rightarrow 4$ & $+4,5$ & $\begin{array}{l}28,8 \rightarrow 30,1 \text { people / ha, which is equal to an increase in the } \\
\text { number of employees by 23.7 thousand people, or a } \\
\text { reduction in the area of farmland by } 819.2 \text { thousand ha for } \\
\text { the same number of employees, or an intermediate option }\end{array}$ \\
\hline $\begin{array}{l}\text { The growth rate of agricultural area of } \\
\text { citizens (including farmers) (S5), \% }\end{array}$ & 0,045 & 0,21 & $-6 \rightarrow-5$ & $+0,09$ & $-1,34 \rightarrow-1,25 \%$ \\
\hline
\end{tabular}

* Developed by the authors

A 1 point change (transition from the estimate of -10 points to -9 points) in the rate of increase in the number of agricultural workers (S2) increases the integrated efficiency of land management by 0,045 (or 0.21\%), which is equivalent to an increase of S2 by $1.7 \%$. In absolute terms, this means an increase in S2 from -6.2 to $-4.5 \%$, which is equal to reduction in the number of employees in agriculture by 9,51thousand people per annum. A 1 point change in the number of farmers per 10,000 rural residents (S3) will not lead to any transitions because of its big value (the score of 10 is maximum), but will increase the integrated efficiency of land management by 0,045 (or $0.21 \%$ ). It should be noted that, even though a large number of farms indicate the entrepreneurial initiative, the farms are significantly behind the agricultural enterprises by capital-land and capital-labor ratio, so they basically show a low level of productivity and land output, are more effective socially than economically and environmentally.

A 1 point change in the number of employees per 1,000 hectares of farmland (S4) - transition from the estimate of 3 points to 4 points - leads to increased integrated efficiency of land management by 0,045 (or $0.21 \%$ ), which is equivalent to an increase in S4 by $4.5 \%$. In absolute terms, this means an increase in S4 from 28.8 to $30.1 \%$, which is equal to an increase in the number of employees by 23.7 thousand people, or reduction of agricultural land by 819.2 thousand ha for the same number of employees, or an intermediate option. A 1 point change in the growth rate of agricultural area of the citizens (including farmers) (S5) - transition from the estimate of -5 to -6 points - leads to an increase in integrated efficiency of land management by 0,045 (or $0.21 \%$ ), which is equivalent to an increase in S5 by $0.09 \%$. In absolute terms, this means an increase in S5 from -1.34 to $-1.25 \%$, which is marginal slowing down of the fall.

\section{Conclusion.}

The defined projections take into account the relationships between individual input parameters and thus can be treated as a tool for managerial decision-making in the presence of various resources and opportunities to achieve social security in rural aread and national sustainable development at the same time.

The authors here focus on the use of conventional point estimates of 45 indices (social, economic and environmental efficiency being at parity) and the map of projected impacts of indices of different kinds of efficiency on each other. The coauthors have determined the projected rating of the impacts of all criterion indices on the estimate of the integrated efficiency of land management. The use of the authors' system of projection matrixes considerably facilitates calculation procedures and the perception of the practical essence of projection of not only social but also economic and environmental efficiency of agricultural land management. The author's proposition is especially relevant in the context of countries' harmonious compliance with the global most 
actual trends, including sustainable development, social security promotion for everyone (and rural territories especially), and food safety too.

The prospects for further developments are seen in determining methodology as scenario modeling (including use of tools of social account matrix), as well as ranking of regions and countries by the efficiency of land management (using techniques of neural programming). It is also reasonable to study measures aimed at optimizing the structure, and, based on it, cumulative growth of the integral index of efficiency for providing the population with sufficient food supply and fair income for rural residents at the same time through rational use of national land resources.

\section{References}

Andreychuk, V. (2006), Effectiveness of agricultural enterprises activity: theory, methodology, and analysis, Kiev: KNEU.

Budzak, V. (2009). Economic and environmental principles of efficient use, protection and reproduction of agricultural lands, pp. 25-33, available on-line at http://economics-of-nature.net/uploads/arhiv/2009/Budziak-Vasil.pdf.

Czyżewski, A., \& Smędzik-Ambroży, K. (2015). Specialization and diversification of agricultural production in the light of sustainable development. Journal of International Studies Vol, 8(2), 63-73.

Chakir, R. and Gallo, J. L. (2013), Predicting land use allocation in France: A spatial panel data analysis, Ecological Economics, Vol. 92, No. 3, pp. 114-125.

Cockfield, G., \& Botterill, L. (2016), Antipodean agricultural and resource economics at 60: agricultural adjustment, Australian Journal of Agricultural and Resource Economics, Vol. 60, No 4, pp. 573-589.

Dedina, D., \& Sánová, P. (2013). Creating a Competitive Advantage by Developing an Innovative Tool to Assess Suppliers in Agri-Food Complex. Journal of Competitiveness, 5(3), 31-45

Delattre, L., Chanel, O., Livenais, C., \& Napoléone, C. (2015). Combining discourse analyses to enrich theory: The case of local landuse policies in South Eastern France, Ecological Economics, Vol. 113, No 2, pp.60-75.

Diesperov, V. (2014), Use of land resources in rural areas, Economic of AIC, No 11, pp. 48-56.

Golyan, V. (2012), Land issue in the context of the revival of rural areas, Kiev, http://vgolian.com/zemelniy-vopros-v-kontexte-vozrozdeniya-selskih-territoriy.html. (retrieved: 15.01.2017).

Homolac, L., \& Karel, T. (2016), Historical development of land ownership in the Czech Republic since the foundation of the Czechoslovakia until present, Agricultural Economics, No 62, pp. 528-536.

Kanash, E. (2009), Effective lever of land resources management, Land management and cadaster, No 4, pp. 10-12.

Khodakivska, O. (2015), Ecologization of agrarian production: modern challenges and perspectives of development, Economic of AIC, No 5, pp. 43-47.

Kirilenko, I., Demyanchuk, V. (2015), Prospects of domestic AIC in light of the global food market forecasts, Economic of AIC, No 1, pp. 21-28.

Knoke, T., Paul, C., Härtl, F., Castro, L.M., Calvas, B., \& Hildebrandt, P. (2009), Optimizing agricultural land-use portfolios with scarce data - A non-stochastic model, Ecological Economics, Vol. 120, No 4, pp. 250-259.

Kvasha, S. (2009), Land relations in the context of agricultural development models in Ukraine, Economic of AIC, No 3, pp. 54-57.

Moroz, A., Karachina, N., Semtsov, V., \& Mandziuk N. (2015), Institutional foundations of opportunistic behaviors in the agrarian sphere in Ukraine, Agro world, No 9, pp. 8-13.

Pankiv, Z. (2008), Land resources, Lviv: LNU im. Ivan Franko.

Pogrishuk, B., \& Pogrishuk, G. (2015), Conceptual principles of strategic development ensure of AIC in terms of European integration economy, Bulletin TSTU, No 1, pp. 7-14.

Pushover, A. (2010), Non - Soil Upturned, Correspondent, No 9, pp. 23-25. 
Official website of FAOSTAT - Food and Agricultural Organization of the United Nations, available on-line at http://faostat.fao.org/ site/342/default.aspx.

Reiff, M., Surmanová, K., Balcerzak, A. P., \& Pietrzak, M. B. (2016). Multiple criteria analysis of European Union agriculture. Journal of International Studies, 9(3), 62-74.

Simanaviciene, Z., Kontautiene, R., \& Simanavicius, A. (2017). Assumptions of Corporate Social Responsibility as Competitiveness Factor. Montenegrin Journal of Economics, 13(3), 149-160.

Shubravska, H. (2015), Development of agricultural production of Ukraine: factors of growth, Economic of AIC, No 5, pp. 5-11.

Shubravska, H., Moldovan, L., \& Paskhaver, B. (2014), Agricultural development of Ukraine in the context of food security, Kiev: Institute of Economics and forecasting of NAS of Ukraine.

Stukach, V. (2013), Mechanisms of motivating the land owners in applying soil protection technologies, Business. Education. Right, Bulletin of the Volgograd Institute of Business, No 3, pp. 106-114.

Sutton, P.C., Anderson, S.J., Costanza, R., \& Kubiszewski, I. (2016), The ecological economics of land degradation: Impacts on ecosystem service values, Ecological Economics, Vol. 129, No 3, pp. 182-192.

Vlasenko, Y., \& Namjasenko, Y. (2015), Role of grain traders in export of domestic wheat, Agro world, No 5, pp. 41-45.

Velychko, O. (2015). Logistical system Fortschrittzahlen in the management of the supply chain of a multi-functional grain cooperative. Economics \& Sociology, 8(1), 127-146.

Urbaniec, M. (2015). Towards Sustainable Development through Eco-innovations: Drivers and Barriers in Poland. Economics and Sociology, 8(4), 179-190

Ward, A., Yin, K., Dargusch, P., Fulton, E.A., \& Ammar, A.A. (2017), The Impact of Land Use Change on Carbon Stored in Mountain Grasslands and Shrublands, Ecological Economics, Vol. 135, No 1, pp. 114-124.

Yung-Chang, W. (2016), The optimal capital structure in agricultural cooperatives under the revolving fund cycles, Agricultural Economics, Czech, No 62, pp. 45-50.

Yerznkyan, B., Gassner, L., \& Kara, A. (2017). Culture, Institutions, and Economic Performance. Montenegrin Journal of Economics, 13(2), 71-80.

Zos-Kior, M., Ilyin, V., \& Bondarskaya, A. (2014), Globalization and land-use prospects for agrarian enterprises, The Advanced Science Journal, No 8, pp. 205-208.

Zos-Kior, M. (2015), National and integration aspects of land administration of agrarian sector of economy, Zaporizhia: LTD NPK "Inter-M". 